\title{
PENENTUAN PENETRASI AIR DAN HIDROKARBON DARI KRISTAL CAIR LAMELAR DALAM SISTEM GARAM NITRAT, SIKLOHEKSANE DAN LAURIL ALKOHOL POLI ETER
}

\author{
Ali Amran \\ Jurusan Kimia FMIPA Universitas Negeri Padang
}

\begin{abstract}
Water and hydrocarbon penetrations of the lamellar liquid crystal in nitrate salts (calcium and aluminium nitrates), cyclohexane, and lauryl alcohol polyether (LA4) system have been investigated. Liquid crystal phase which characterized using optical polarizing microscope and small-angle X-ray diffraction, showed a significantly the water and the hydrocarbon penetrations of aluminium nitrate and calcium nitrate solutions.
\end{abstract}

Keywords: Lamellar liquid crystal, Optical polarizing microscope, Water and hydrocarbon penetration, Nitrate salts (calcium and aluminium nitrates), Lauryl alcohol polyether (LA $\left.A_{4}\right)$, Smallangle $X$-ray diffraction.

\section{DAFTAR PUSTAKA}

1. P. Ekwall, In Advanses in Liquid Crystals, G.H. Brown Ed., Academic Press, New York, 1975, 1, 1- 142.

2. G. J. T. Tiddy, Surfaktant-water liquid crystal phases, Phys. Reports, $1-46$, (1980)

3. O. Robles-Vasquesz, J. F. A. Saltero, J. E. Pulg, S. B. Tripoli, E. Valles, and O. Manero, Rheology of lyotropic liquid crystals of Aerosol OT, J. Colloid Interfece Sci., 160: 65 - 71, (1993).

4. G. T. Dimitrova, Th. F. Thadros, and P. F. Luckman, Invetigations of the phase changes of nonionic surfactant using microscopy, differential colorimetry, and rheology. 1 synperonic $\mathrm{A} 7$, a $\mathrm{C}_{13} / \mathrm{C}_{15}$ alcohol with 7 mole of ethylene oxide, Langmuir, 11, 1101 - 1111, (1965).

5. F. Cordobes, J. Munoz and C. Gallegos Linear Viscoelasticity of Direct Hexagonal liquid Crystalline Phase for Heptane/Nonionic Surfactant/Water System, J. Colloid Interface Sci., 187, 401 - 417, (1997).

6. H. A. Barnes, Detergents in Rheometry Industrial Applications, K. Walters (Ed.), John Wiley \& Sonn, New York, 1980, 33 110.
7. F. Cormelles, J. Caelles, A. Pascual, and Sanchaz, J. Leal, 18-th International I.F.S.C.C. Congress, Venice, 1994.

8. S. Muller, C. Borschig, W. Gronski, and C. Schmidt, Shear-Induce states of orientation of the lamellar phase of $\mathrm{C}_{12} \mathrm{E}_{4} /$ water, Langmuir, 15, 7558 - 7564, (1999).

9. S. Engstrom, Drug Delivery from Cubic and other Lipid-Water Phases, Lipid Technol., 2, 42 - 45, (1990).

10. S.E. Friberg, Application of Amphiphilic Association Structures, Adv. Colloid Interface Sci., 32, 167 - 182, (1990).

11. J. D. Mitchell, G.J.T. Tiddy, L. Waring, T. Bostock, and M. P. Modonald, Phase Behaviour of Polyoxyethylene Surfactants with Water, J. Chem. Soc. Faraday Trans., 79, 975 - 991, (1983).

12. J. M. Franco, J. Munov, and C. Gallegos, Transient and steady flow of a lamellar liquid crystalline surfactant/water system, Langmuir, 11, 8653 - 8663, (1995).

13. J. E. Moros, F. Cordobes, C. Gallegos, and J. M. Franco, Linear Viscoelasticity of Concentrated Polyethylene Glycol Tertraoctylphenyl ether solutions, J. Dispersion Sci. Technol., 22, 409 - 420, (2001).

14. G. H. Brown, and J. J. Wolken, Liquid crystals and biological structures, Academic Press, New York, 1979, 200. 
15. R. Lipowsky, E. Sachman, Eds., Handbook of Biological Physics, Elsevier Science, Netherlands, 1995

16. J. M. Seddon, R. H. Templer, $\mathrm{CH}_{3}$ in Structure and Dynamics of membrane: From cells to vesicles, A. J. Hoff, Elsevier Sciemce, Netherlands, 1995.

17. E. Moldoveanu, D. Marta, G. Burdecea, Apoptosis. Int. Symp. Of Myelodisplastic Sindrome, Proc., 51 - 56, Paris $15-17$ May 2003.

18. Y. Bouligand, Liquid crystals and their analogs in biological systems, Solid State Physics, supplement 14, (1978).

19. S. Hoffmann, W. Witkowsky, ChiralityFrom weak bosons to $\alpha$-Helix, Sringer, Heidenberg, 225, 1991.

20. S. Hoffmann, W. Witkowsky, Reproduction of supermolecular structure, Kluwer. Dordrecht NATO ASI Ser., 496, 1994.

21. G. M. Palleos, J. Michas, MembranaNucleuic Acids system, Liq. Cryst., 11, 773, (1992).

22. I. H. Blank, J. Moloney, A. G. Emsile, and I. Apt. C. Simon, The diffusion of water across the stratum corneum as a function of its water content, J. Invest. Dermatol, 82, 188 - 194, (1984).

23. W. P. Smith, M. S. Christenson, and E. H. Gans, Effents of lipids on the aggregation and permeability of human stratum corneum, J. Invest. Dermatol, 78, 7 - 11, (1982).

24. S. E. Friberg, L. Goldsmith, A. Suhaimi, snd R. D. Rhein, Surfactants and the stratum corneum, Colloid and Surfaces, 30, $1-2,(1980)$.

25. A. J. I. Ward, H. Ku, M. A. Phillippi, and C. Marie, Order of parameter polyethylene chain in the lamellar phase of a non-ionic surfactant, Mol. Cryst. Liquid Cryst., 154, $55-60,(1988)$.

26. G. Grubauer, K. R. Feingold, R. M. Haris, and P.M. J. Elias, Lipid content and lipid type as determinants of the epidermal permeability barrier, J. Lipid Res., 30, 89 96, (1989).

27. S. E. Friberg, L. Goldsmith, A. Suhaimi, snd R. D. Rhein, Surfactants and the stratum corneum, Colloid and Surfaces, 30, $1-2,(1988)$.

28. S. E. Friberg, I. Kayali, T. Suhery, L. D. Rhein, and F. A. Simon, Lyotropic liquid crystals and the structural lipids of stratum corneum, J. Pharm. Sci., 80, 5, (1991).

29. S.E. Friberg, Application of Amphiphilic Association Structures, Adv. Colloid Interface Sci., 32, 167 - 182, (1990).

30. S. E. Friberg, and I. Kayali, Water evaporation rates from model of stratum corneum lipids, 78:(8) 639, (1989).

31. Ward, A. J. I., and Tallon, R., Penetration enhancer incorporation in belayers, $J$. Ind. Dev. Perm., 14, 1155 - 1166, (1988).

32. A. J. I. Ward, I. Kayali, and S. E. Friberg, Langmuir, 1152 - 1166, (1989).

33. S. E. Friberg, and Ma, Zu-ning, Hydrolysis of tetraethoxysilane in a liquid crystal, in microemulsion and in a solution, J. Disp. Sci. Technol., $147-148,30-35$, to be published, (1992).

34. A. Amran, Microemulsion, gel process to prepare combination glasses, (Ph.D desertation), Departement of Chemistry, Clarkson University, Potsdam, New York, USA, 1993. 